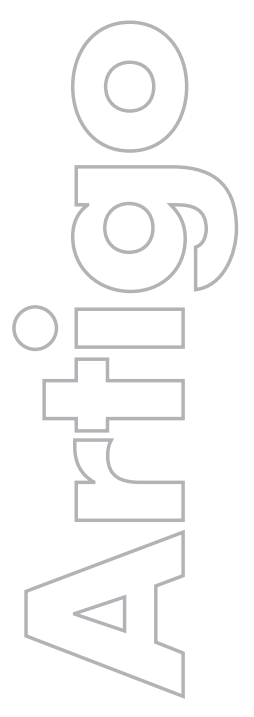

\section{revista}

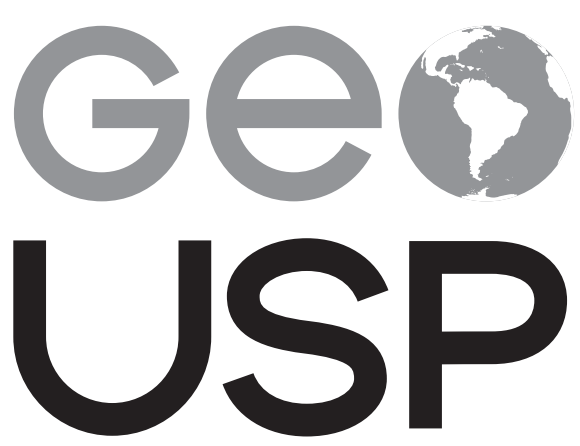

espaço e tempo

Volume 18, no 1 (2014)

\section{Geoprocessamento aplicado ao zoneamento ambiental da bacia do alto rio coxim-ms}

\author{
Vitor Matheus Bacani \\ Universidade Federal de Mato Grosso do Sul, \\ Campus de Aquidauana
}

Ailton Luchiari Universidade de São Paulo

p. $184-197$

Artigo disponível em:

http://www.revistas.usp.br/geousp/article/view/81098

Como citar este artigo:

BACANI, V. M.; LUCHIARI, A. Geoprocessamento aplicado ao zoneamento ambiental da bacia do alto rio Coxim-MS. GEOUSP - Espaço e Tempo (Online), São Paulo, v. 18, n. 1, p. 184-197, 2014.

\section{(cc) $\overline{E Y}$}

Este artigo está licenciado sob a Creative Commons Attribution 3.0 License. 


\title{
Geoprocessamento aplicado ao zoneamento ambiental da bacia do alto rio coxim-ms
}

Vitor Matheus Bacani

Ailton Luchiari

\section{Resumo}

Este trabalho elaborou um zoneamento ambiental configurado num mapa síntese de ordenamento físico-territorial da bacia do alto rio Coxim (BAC), MS.

Os procedimentos metodológicos fundamentaram-se na estruturação de um banco de dados geográficos implementado num sistema de informação geográfica. Os resultados indicaram que as áreas utilizadas pela pecuária são mais sensíveis à ocupação que as sob manejo da agricultura mecanizada. Foi possível estabelecer áreas prioritárias para preservação, conservação e de uso sustentável.

Palavras-chave: Ordenamento territorial. Zoneamento ambiental. Fragilidade ambiental. Geotecnologias. Rio Coxim.

\section{Geoprocessing applied to environmental zoning in the Upper Coxim River Basin, MS}

\begin{abstract}
The aim of this study was to develop an environmental zoning set in a synthesis map of physical and territorial planning of the Upper Coxim River Basin (UCB), MS. The methodological procedures were based on the structuring of a geographic database implemented in a Geographic Information System. The results showed that areas associated with livestock activity are more sensitive to the occupation under the management of mechanized agriculture. It was possible to establish priority areas for preservation, conservation and sustainable use.
\end{abstract}

Keywords: Territorial management. Environmental zoning. Environmental fragility. geotechnology. Upper Coxim River Basin (UCB). 


\section{Introdução}

As geotecnologias (ou geoprocessamento) constituem-se como um conjunto de procedimentos, técnicas e produtos destinados à coleta e o tratamento de informações espaciais. Trata-se de um termo relativamente recente na Geografia, que abriga diversas áreas do conhecimento, tais como: o sensoriamento remoto, a cartografia digital, os sistemas de informação geográfica, os sistemas de posicionamento global via satélite, a topografia, entre outras.

A transformação dos ambientes naturais em áreas de cultivo é, sem dúvida, a maior intervenção do homem no meio ambiente. A evolução da agricultura para sistema de uso intensivo ou cultivos múltiplos, onde a mesma área é cultivada ininterruptamente, com pouca atenção às suas fragilidades e vocações tem causado impactos em muitas regiões. Em decorrência das mudanças na agricultura, do crescimento demográfico, da evolução industrial, dentre outros, vários problemas foram surgindo, principalmente a partir do século XX (Silva, 2003).

As políticas de incentivo à expansão das fronteiras agrícolas somadas às favoráveis condições edáficas da bacia do alto rio Coxim (BAC) têm evidenciado profundas alterações na paisagem, acarretando problemas ambientais diversos e ainda muito pouco conhecidos. Contudo, torna-se de vital importância a elaboração de um zoneamento ambiental para que se estabeleça uma política eficaz de ordenamento territorial.

O zoneamento ambiental consiste em dividir uma área em parcelas homogêneas, com características fisiográficas e ecológicas semelhantes, nas quais se autorizam determinados usos e atividades e se interditam outros (Brasil, 1991).

A elaboração do zoneamento ambiental deve contemplar segundo Becker e Egler (1996) os seguintes aspectos:

a) representar instrumento técnico de informações sobre o território, necessária para a sua ocupação racional e o uso sustentável dos recursos naturais;

b) prover uma informação integrada em uma base geográfica;

c) classificar o território de acordo com a sua capacidade de suporte ao uso e ocupação.

d) ser condicionante de planejamento e gestão para o desenvolvimento em bases sustentáveis, colocando-se como instrumento corretivo e estimulador desse desenvolvimento.

Segundo Brasil (1991), o zoneamento ambiental possui vantagens por:

a) permitir que se determine limite de possíveis irreversibilidades, devido a conflitos ambientais e pontos de fragilidade biológica, antes que se tomem decisões sobre o uso de cada área, que de outra forma poderiam causar danos irreversíveis; tendo, portanto, caráter preventivo;

b) identificar as atividades antrópicas para cada setor da unidade Ambiental e seu respectivo manejo, possibilitando a descentralização de comando e decisão; e

c) pelo fato da metodologia do zoneamento ambiental ser flexível, permite que se adapte a definição de manejo de uma zona.

Nesse sentido, o zoneamento ambiental é tido como a base principal para elaboração de um modelo de ordenamento físico-territorial e deve ser visto como um instrumento cuja finalidade é auxiliar a formulação de políticas e estratégias de desenvolvimento a serem implementadas na BAC. 
O objetivo deste trabalho foi elaborar um zoneamento ambiental configurado num mapa síntese de ordenamento físico-territorial da bacia do alto rio Coxim (BAC), MS, organizado num sistema de informação geográfica (SIG).

\section{Área de estudo}

A área de estudo é a bacia do alto rio Coxim (BAC), que apresenta uma área de aproximadamente $1.375 \mathrm{~km}^{2}$. A BAC abrange parte dos municípios de São Gabriel do Oeste e Camapuã, situados na porção centro-norte do estado do Mato Grosso do Sul, na microrregião do Alto Taquari (Figura 1).

\section{Figura 1}

\section{Loclalização da área de estudo}
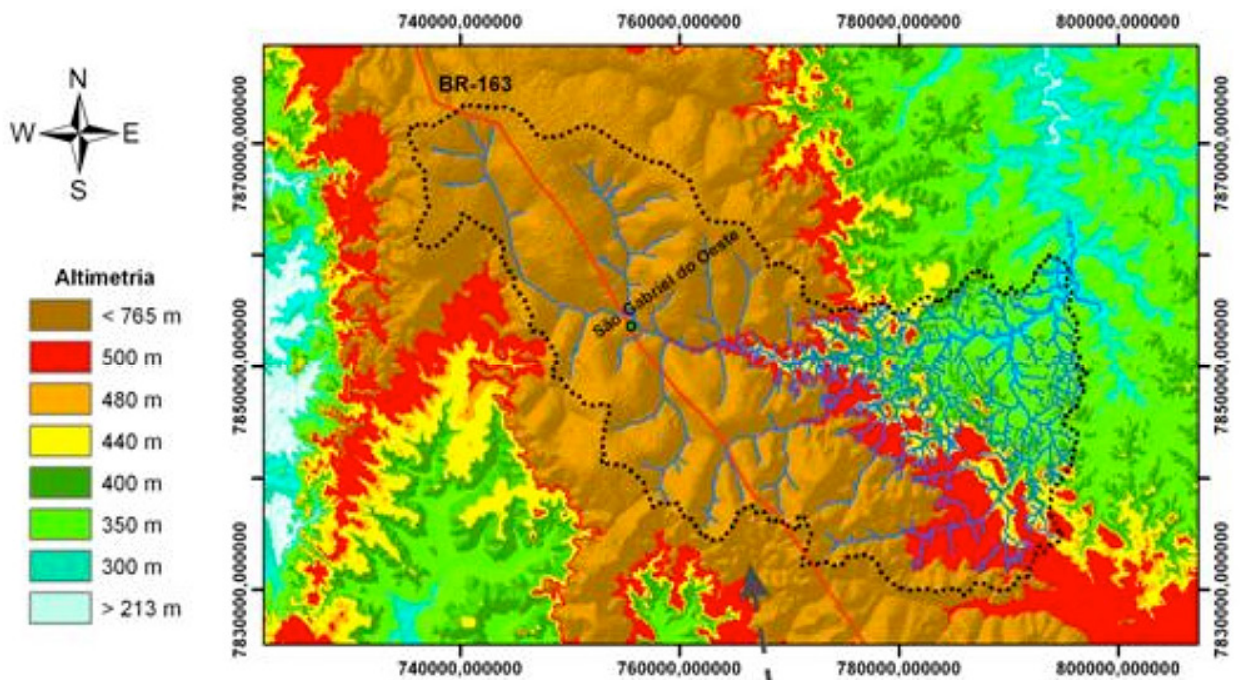

Convençðes Cartográticas

- Sede Municipal

- Drenagem

- Estrada Pavimentada

Limite da Bacia

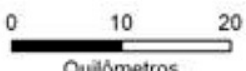

$780000,000000 \quad 800000,000000$ 


\section{Caracterização da área de estudo}

A cobertura vegetal natural é composta por savana arbórea densa e savana arbórea aberta, sem floresta de galeria. Entretanto, a cobertura vegetal predominante na BAC é agrícola de culturas cíclicas (Brasil, 1982; Abdon, 2004). A área agrícola da bacia concentra-se no município de São Gabriel do Oeste, enquanto em Camapuã predomina a pastagem.

○ clima é do tipo Aw, segundo Köppen (clima de Savana), com regime pluviométrico tipicamente tropical, com 80\% das chuvas concentradas entre os meses de outubro e março. A média do total pluviométrico anual na área da BAC é 1.489,6 mm e a evapotranspiração anual é superior a $1140 \mathrm{~mm}$ (Abdon, 2004).

A geologia da BAC é constituída por uma unidade edafoestratigráfica composta por coberturas detrito-lateríticas neogênicas (Tndl), basaltos da formação serra geral (JKsg), e arenitos da formação piramboia (TRpi) e do grupo Bauru (Brasil, 1997).

A BAC é constituída pela unidade geomorfológica morfoestrutural da bacia sedimentar do Paraná e pelas morfoesculturas da chapada de São Gabriel e do planalto do Taquari, seguidas respectivamente pelas formas erosivas com superfície pediplanada e formas de dissecação convexa.

A unidade morfoescultural da chapada de São Gabriel compreende a região dos chapadões residuais da bacia do Paraná, caracterizada como uma extensa superfície pediplanada, que possui posição geográfica individualizada, visto que se ressalta em meio a um relevo mais rebaixado e dissecado. A chapada destaca-se pela dominância de modelados planos, com altitude média de 700 metros. A unidade é delimitada em quase toda a sua volta por escarpas erosivas estruturais e ressaltos topográficos decorrentes da presença de rochas eruptivas da formação serra geral. $\bigcirc$ relevo é esculpido em litologias da unidade edafoestratigráfica detrítico-laterítica sobre as quais desenvolvem-se Latossolos Vermelhos Álicos. A escarpa basáltica que contorna a unidade é dominada pelo cerradão, enquanto o topo do planalto é caracterizado como área antrópica na região de savana (MS, 1990).

Na unidade morfoescultural do planalto do Taquari, destacam-se as depressões interiores da região geomorfológica dos planaltos arenítico-basálticos Interiores. Trata-se de áreas topograficamente deprimidas (entre 300 e 500 m), via de regra cercadas por escarpas e bordas de patamares estruturais, como no caso da BAC, pela chapada de São Gabriel, que acentua o aspecto da depressão. A unidade é esculpida em litologias do grupo São Bento, originando modelados de dissecação colinosos e secundariamente tabulares, constituídos por neossolos quartzarênicos e argissolos vemelho-amarelos.

\section{Materiais e métodos}

A fundamentação teórico-metodológica que subsidiou o emprego das geotecnologias no diagnóstico e prognóstico ambiental da BAC se apoia na análise integrada do ambiente, pautada na concepção das unidades ecodinâmicas, preconizadas por Tricart (1977) e Tricart e Kiewietdejonge (1992) e Ross (2006). Este procedimento fundamenta-se na análise da fragilidade empírica proposta por Ross (1994), apoiado no princípio de que a natureza apresenta funcionalidade intrínseca entre seus componentes físicos e bióticos. As unidades de fragilidade dos ambientes naturais devem ser resultantes dos levantamentos básicos de geomorfologia, 
solos, cobertura vegetal/uso da terra e clima. Esses elementos tratados de forma integrada possibilitam obter um diagnóstico das diferentes categorias hierárquicas da fragilidade dos ambientes naturais.

Para elaboração do mapa de zoneamento ambiental, além da cartografia da fragilidade ambiental foi necessário espacializar as áreas que apresentam restrições legais a ocupação no denominado mapa de legislação ambiental. $\bigcirc$ mapeamento realizado visou à identificação das áreas de preservação permanente (APP), segundo as leis ambientais presentes no Código Florestal Brasileiro, Lei Federal n. 4.771/1965, e as resoluções do Conselho Nacional do Meio Ambiente n. 302 e n. 303/2002. Este documento cartográfico caracteriza-se como uma das principais ferramentas voltadas ao ordenamento territorial, pois combinado com os mapas de uso da terra/cobertura vegetal e de fragilidade ambiental, possibilitou o estabelecimento de zonas homogêneas da paisagem, onde se propõe recomendações referentes aos modos de exploração sustentável do ambiente.

Este procedimento de elaboração do zoneamento ambiental está fundamentado na proposta de Ross (2006). Foram combinados no SIG por meio dos métodos de álgebra de campos por sobreposição ponderada, os mapas temáticos referentes aos tipos de solos, clinográfico e de potencial natural à erosão (dados não mostrados), para determinação das zonas produtivas, as de restrições legais e as zonas de incongruências que consistem em realizar associações causais entre o uso empírico da terra e as determinações legais para proteção da mesma, de modo a identificar as áreas que obedecem ou não a legislação. Estes procedimentos foram realizados no software ArcGIS 9.2, onde foram atribuídas porcentagens de influências iguais aos diferentes "pesos" de cada uma das variáveis (Tabela 1).

\section{Tabela 1}

Critérios estabelecidos para elaboração do zoneamento ambiental

\begin{tabular}{l|l|l}
\hline \multirow{2}{*}{ zona } & categoria & critérios \\
\hline \multirow{2}{*}{ Zona de Restrições Legais } & APP & legislação ambiental \\
\cline { 2 - 3 } & vegetação natural & remanescentes florestais \\
\hline \multirow{2}{*}{ baixa restrição } & $\begin{array}{l}\text { declividade }<6 \% \text { potencial à erosão e } \\
\text { fragilidade ambiental muito baixa }\end{array}$ \\
\cline { 2 - 3 } & média restrição & $\begin{array}{l}\text { declividade entre 6\% e 20\%; potencial à } \\
\text { erosão e fragilidade ambiental de baixa a } \\
\text { média }\end{array}$ \\
\cline { 2 - 3 } & alta restrição & $\begin{array}{l}\text { declividade }>20 \% ; \text { potencial à erosão e } \\
\text { fragilidade ambiental alta ou muito alta }\end{array}$ \\
\hline Zona Urbana & área urbanizada & área construída homogênea \\
\hline \multirow{2}{*}{ Zona de Incongruência } & $\begin{array}{l}\text { conflito entre uso da terra } \\
\text { e legislação ambiental }\end{array}$ & combinação de APP com áreas antropizadas \\
\hline
\end{tabular}


A elaboração do mapa síntese de ordenamento físico-territorial da BAC é resultado da combinação das zonas de restrição à produtividade, geradas no mapa de zoneamento ambiental, do mapa de legislação ambiental e do mapa de uso da terra e cobertura vegetal, implementados no software ArcGIS 9.2. Como resultado final, foram indicadas as áreas prioritárias à preservação, recuperação ou de uso sustentável.

\section{Resultados e discussão}

O mapeamento da fragilidade ambiental encontra-se apresentado na Figura 2.

Mais de 80\% da BAC enquadra-se como área de média fragilidade ambiental, isso deve significar uma ocupação cautelosa, sobretudo na área de exploração agrícola, onde dominam as médias fragilidades. Exatamente sobre as áreas de relevo mais dissecado, em solos com maior propensão à erosão é onde ocorrem as áreas de maior fragilidade ambiental, o que deve ser interpretado como áreas muito sensíveis à exploração antrópica. Esta classe corresponde às áreas de forte fragilidade, assentadas sobre litologias psamíticas e, consequentemente, solos arenosos e relevo dissecado com fortes inclinações.

As áreas mapeadas como muito frágeis correspondem a pouco menos de $1 \mathrm{~km}^{2}$, situadas na escapa erosiva basáltica que divide a chapada de São Gabriel dos demais planaltos sedimentares do Paraná.

\section{Figura 2}

\section{Mapa da fragilidade ambiental}

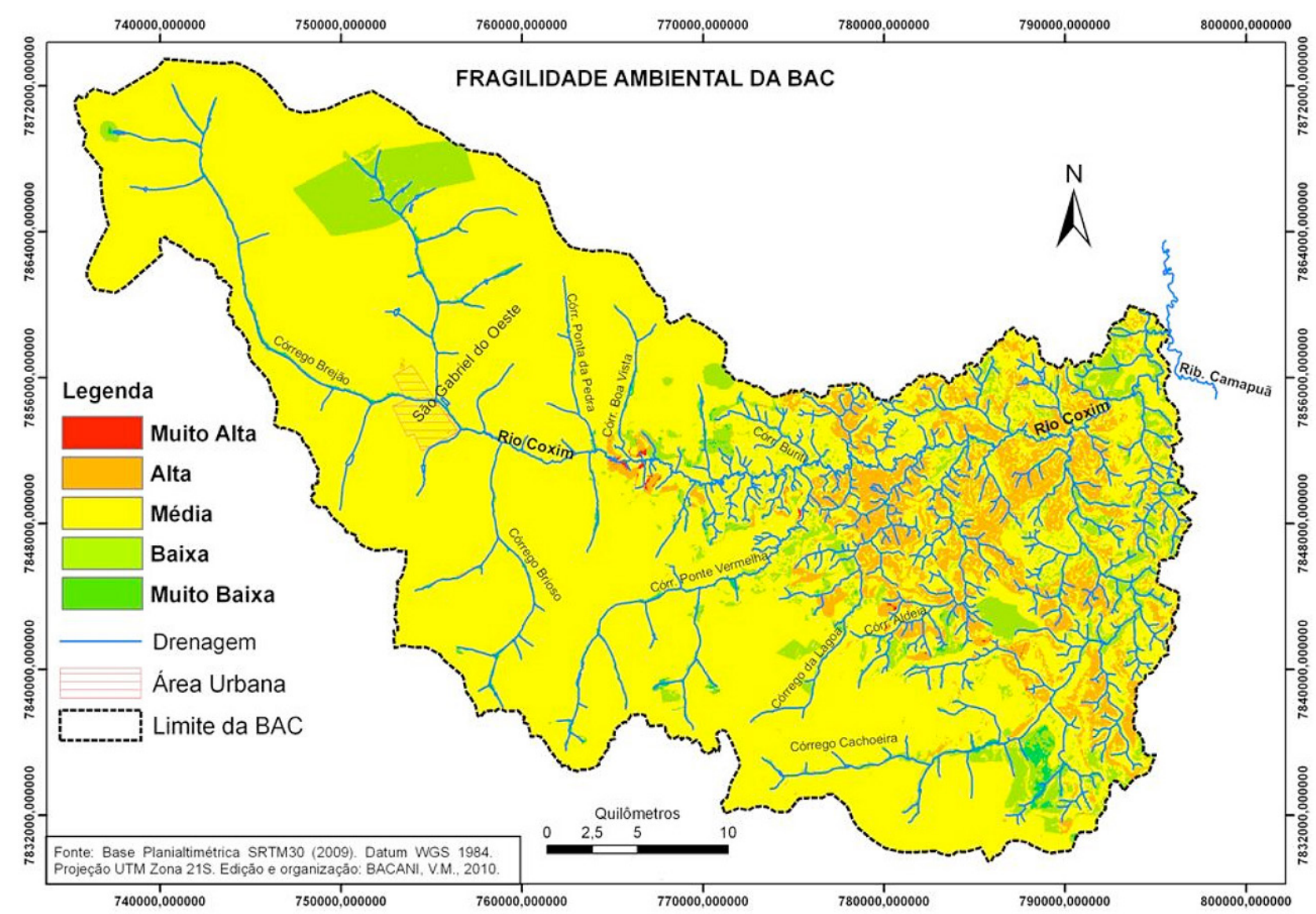


A Figura 3 apresenta o mapa de legislação ambiental da BAC, relacionado com a ocupação do solo: uso antrópico e vegetação natural. Foram identificadas cinco tipo de APP, segundo determinações do Código Florestal Brasileiro (Brasil, 1965) e Resoluções Conama (Brasil, 2002a; Brasil, 2002b), a saber: a) distâncias de 30m de cursos d'água; b) distâncias de 50m de cursos d'água; c) distâncias de 50 m no entorno das áreas de nascente, d) distância de 50m de lagoas, lagos ou reservatórios, tanto naturais quanto artificiais; e e) topos de morros.

$\bigcirc$ trecho em que o rio Coxim corta a chapada de São Gabriel apresenta uma drenagem com largura inferior a 10 metros, portanto o buffer (mapa de distância) gerado foi de 30 metros. Ainda sobre a chapada observou-se APP ligadas às áreas de nascente, onde gerou-se um raio de 50 metros, além de muitas lagoas, a maioria delas artificiais (represas) destinadas à irrigação agrícola.

\section{Figura 3}

\section{Mapa de legislação ambiental}

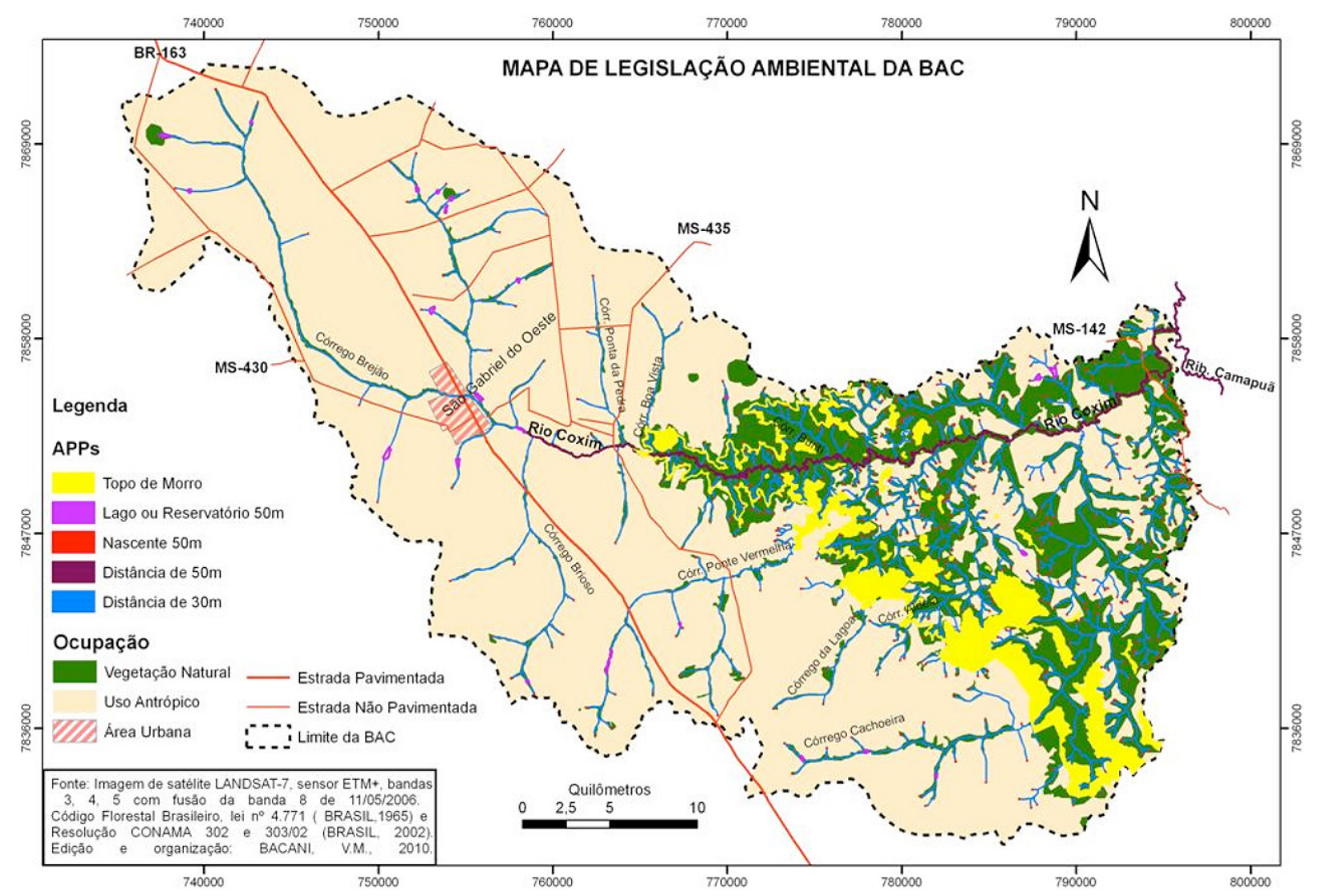

Toda borda da chapada de São Gabriel foi mapeada como APP e incluída na classe topo de morro. As APP de topos de morros encontram-se dominantemente sobre as áreas de relevo mais dissecado e de maior fragilidade ambiental.

O rio Coxim, ao adentrar os morros do planalto do Taquari, alarga seu curso entre $10 \mathrm{e}$ 50 metros, até encontrar-se com as águas do ribeirão Camapuã, foz estabelecida para a BAC. Com isso, o buffer gerado para o canal principal foi de 50 metros e de 30 metros para seus demais afluentes por se tratarem de córregos com larguras nunca superiores a 10 metros. 
A sobreposição dos topos de morros e buffers na ocupação antrópica e natural favoreceu a verificação de áreas que já se encontram em desacordo com a legislação e, sobretudo, estabeleceu critérios para uma reordenação territorial, visto que se trata de um ambiente fortemente antropizado.

Embora a ocupação antrópica intensa na BAC tenha ocorrido após a publicação do Código Florestal (Brasil, 1965), observa-se um forte descumprimento do mesmo. A este problema, atribui-se a ausência de um programa de monitoramento ambiental efetivo que favoreça uma fiscalização adequada. Todavia, a bacia mapeada apresenta áreas de difícil acesso e longas distâncias, entretanto a utilização das geotecnologias enquanto ferramenta de planejamento e gestão ambiental constitui-se numa das mais poderosas armas no sentido de reverter este preocupante quadro.

A Figura 4 corresponde ao mapa de zoneamento ambiental da BAC. Foram mapeadas quatro zonas, a saber: a) Zona de Restrições Legais; b) Zona Produtiva Rural; c) Zona Urbana; e d) Zona de Incongruências.

\section{Figura 4}

\section{Zoneamento ambiental da BAC}

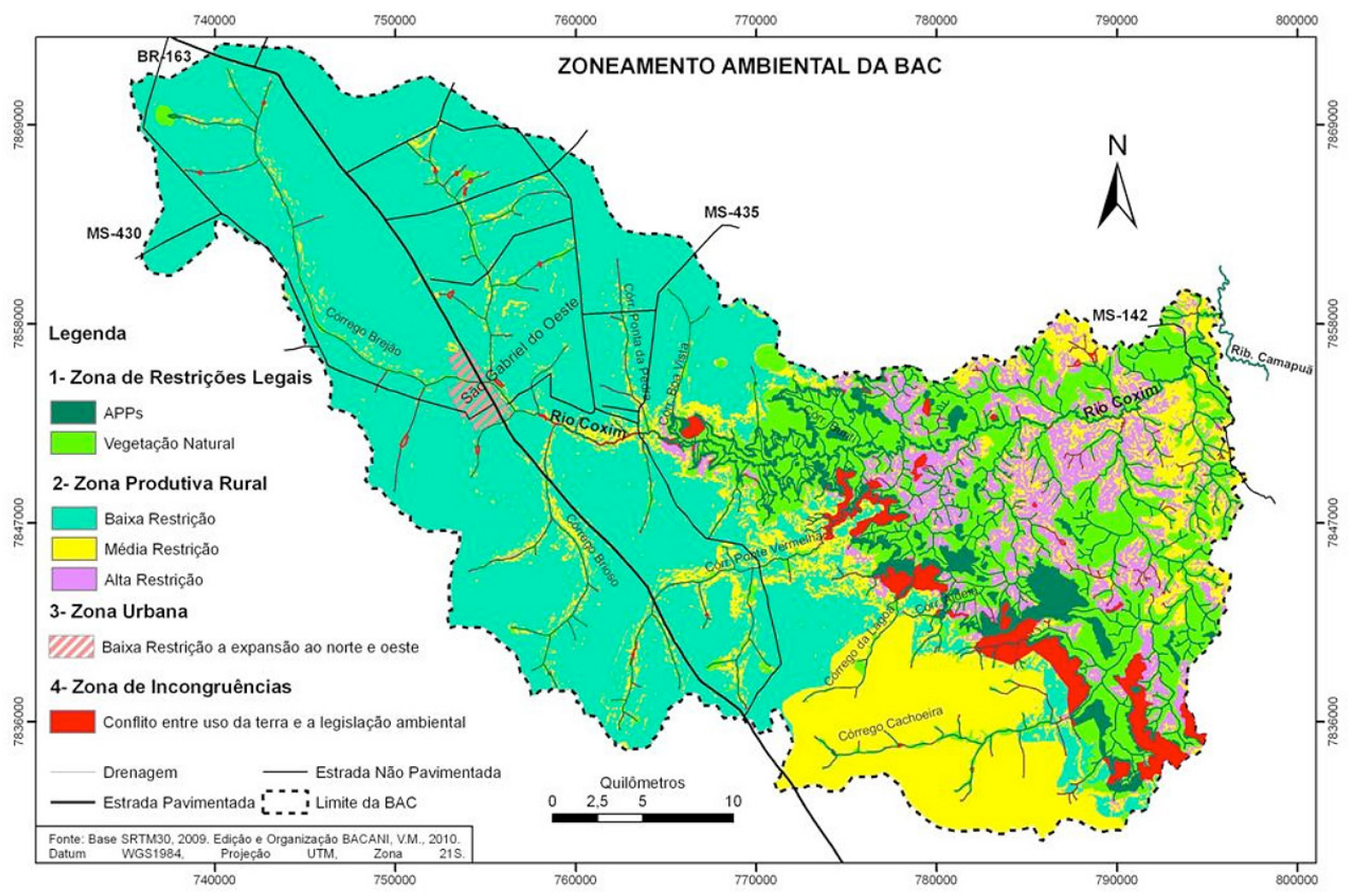

A Zona de Restrições Legais corresponde às APPs e às áreas de vegetação natural. A inclusão desta última deve-se ao fato da área mapeada caracterizar-se por forte antropização, associada ao desflorestamento.

A Zona Produtiva Rural foi compartimentada em três categorias, quanto ao grau de restrição do meio físico à ocupação. 
A classe definida como de baixa restrição, corresponde, genericamente, as vertentes convexas da chapada de São Gabriel, dominada por declividades inferiores a 6\%, e classificada como área de muito baixo potencial natural à perda de solo e fragilidade ambiental. Contudo, a baixa restrição à ocupação não isenta a necessidade da utilização de técnicas conservacionistas e a correção da fertilidade dos solos, que embora sejam, via de regra, argilosos, necessitam de correções tais como a calagem para redução da acidez e a adubação para reposição de macro e micronutrientes do solo.

As áreas correspondentes ao médio grau de restrição a exploração, constituem-se áreas de baixo a médio potencial à erosão e fragilidade ambiental, e apresentam declividades entre 6 e 20\%. Abrange as áreas marginais das APPs ou fundos de vales encaixados na chapada e as áreas de colinas do planalto do Taquari e predominantemente sobre o planalto de Maracaju-Campo Grande, que embora apresente topos tabulares e não tenha declividades tão acentuadas, trata-se de uma área onde dominam arenitos vermelhos e róseos, de granulação média a grosseira do grupo Bauru, e solos predominantemente arenosos (Latossolo Vermelho com associação de Neossolo Quartzarênico).

As Zonas Produtivas Rurais enquadradas na modalidade de alta restrição compreende as áreas mais sensíveis à ocupação, porém podem ser exploradas. Caracterizam-se por apresentar declividades superiores a 20\%, elevados graus de fragilidade ambiental e potencial natural à erosão, classificados entre médio a muito forte. Além das acentuadas declividades, que impedem o emprego da mecanização agrícola dessas áreas, é somada a baixa fertilidade dos solos quando, comparados a chapada.

Contudo, é válido ressaltar que os níveis de restrição à utilização da terra apoiam-se nas características físico-naturais da área e que, conforme aumenta o grau de restrição, aumentam-se as exigências tecnológicas de manejo para exploração de práticas econômicas específicas.

A Zona Urbana corresponde ao sítio urbano de São Gabriel do Oeste que se encontra assentado sobre uma área com baixa restrição à ocupação, porém situado nas margens do rio Coxim, o que sugere risco de inundação, pois a ocupação antrópica faz-se muito próxima ao curso d'água principal, por vezes comprometendo a qualidade ambiental do mesmo. Com isso, verifica-se que as áreas preferenciais à expansão urbana devem ocorrer nos sentidos norte e oeste, onde o relevo apresenta-se suavemente mais elevado e distante da área ocupada pela mata ciliar, o que diminui significativamente os impactos ambientais negativos.

A denominada Zona de Incongruência originou-se basicamente da combinação do mapa de legislação ambiental com o de uso e cobertura da terra simplificado, ou seja, apontando somente as áreas de vegetação natural e as de uso antrópico.

A Zona de Incongruência equivale exatamente às áreas de utilização ilegal da terra, caracterizada pela exploração de áreas de preservação permanente, que deveriam permanecer intocadas segundo a legislação ambiental. $\bigcirc$ problema principal reside no fato de se tratar de unidades ecodinâmicas extremamente frágeis e, portanto exigem medidas de recuperação. Constituem-se de matas ciliares, áreas de nascentes, represas e topos de morros com elevadas inclinações.

O mapa de ordenamento físico-territorial da BAC é apresentado na Figura 5. Este mapa caracteriza-se como um documento de síntese das análises ambientais realizadas na área de estudo e estabelece diretrizes para uma utilização sustentável a partir de recomendações suge- 
ridas. As indicações feitas estão pautadas principalmente em informações presentes no mapa de zoneamento ambiental, mapa de legislação ambiental, mapa de uso da terra/cobertura vegetal e fragilidade ambiental.

As informações presentes no mapa de ordenamento territorial apontam, de modo geral, três tipos de recomendações: áreas prioritárias à preservação permanente, áreas prioritárias à recuperação e preservação e áreas destinadas ao uso sustentável, conforme especificações indicadas a seguir:

a) Áreas prioritárias à preservação permanente: recomenda-se nesta classe as áreas mapeadas como APPs e inclui-se também os remanescentes florestais, pois trata-se de um uma área fortemente antropizada e com alta susceptibilidade à erosão. De acordo com o Código Florestal Brasileiro (1965), a manutenção da vegetação para atenuação dos processos erosivos deve ser preservada. Via de regra, toda essa área indicada como prioritária à preservação permanente está sobre as áreas de maior fragilidade ambiental, e sua manutenção é de extrema importância para a estabilidade ecológica da região.

\section{Figura 5}

\section{Mapa de ordenamento físico-territorial}

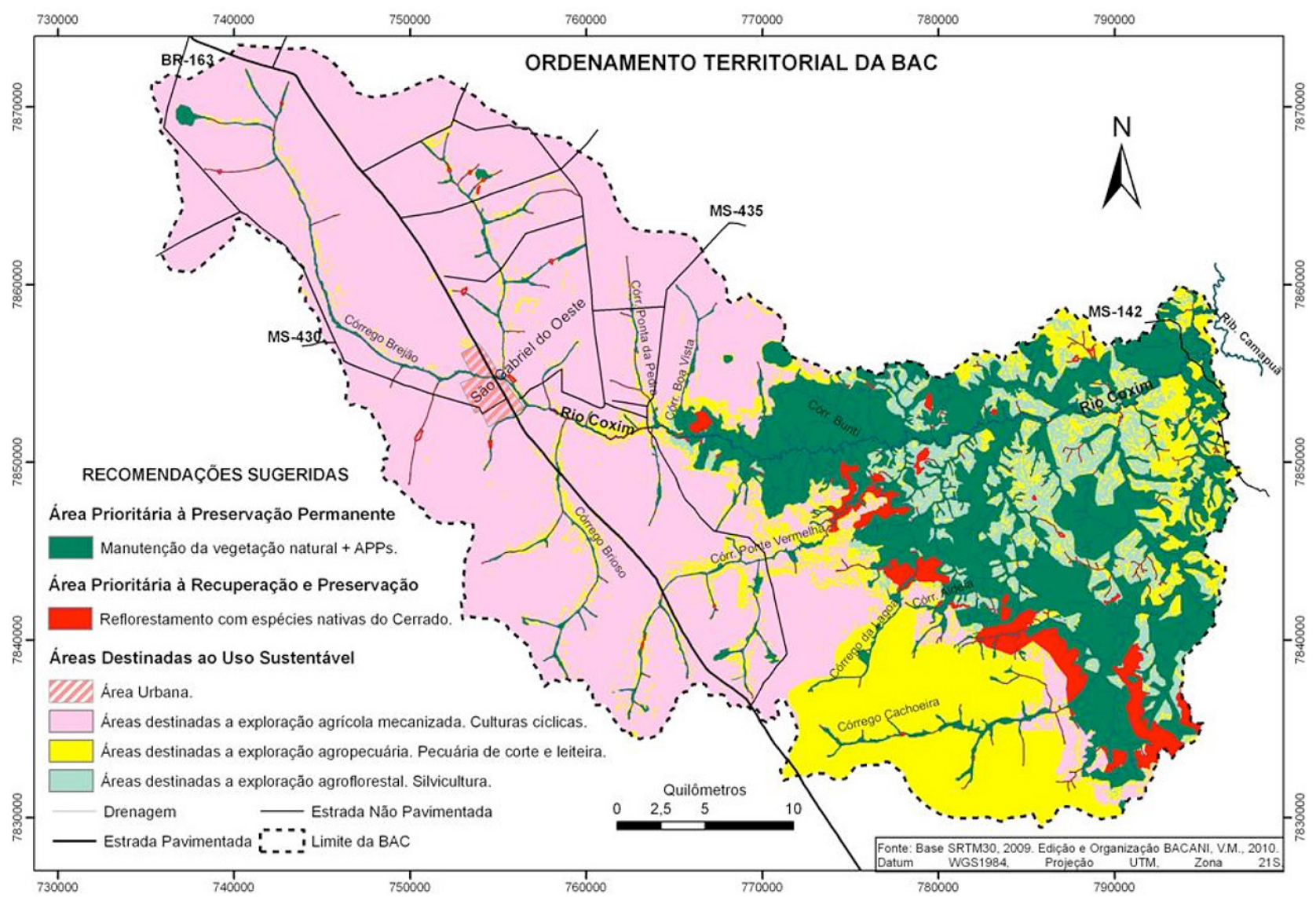

Um dos maiores desafios em relação ao estabelecimento desta zona é a sua manutenção, pautada numa fiscalização que deverá ser mais efetiva, sobretudo com os avanços tecnológicos apoiados nas geotecnologias incluindo o monitoramento via satélite. 
b) Áreas prioritárias à recuperação e preservação: correspondem exatamente à zona de incongruência entre o uso da terra e as APP, que são ambientes delicados, muito frágeis e com elevado potencial natural à perda de solos. Além disso, boa parte situa-se em topos de morros com declividades superiores a 30\%, restringindo absolutamente a ocupação. Estas áreas caracterizam-se como de ocupação ilegal, portanto evidenciam crimes ambientais como o desmatamento de matas ciliares.

A recomendação dada para recuperação e preservação desses ambientes é restringir totalmente o uso antrópico e realizar o replantio de espécies nativas do cerrado, caracterizado como vegetação primitiva.

c) Áreas destinadas ao uso sustentável: as áreas destinadas ao uso sustentável foram indicadas a partir dos graus de restrição à utilização das zonas produtivas propostas no mapa de zoneamento ambiental.

Foram mapeadas três classes destinadas ao uso sustentável: áreas destinadas a cultivos agrícolas; área favorável à exploração da pecuária; e área destinada a exploração agroflorestal/ silvicultura.

Nas áreas mapeadas com baixo grau de restrição natural à exploração da terra, sugeriu-se a utilização pela agrícola mecanizada, o que concorda com o uso atual em grande parte do polígono recomendado, apresentando divergência somente nas Zonas de Incongruência e sobre o compartimento geomorfológico do planalto de Maracaju-Campo Grande, onde a litologia, que favoreceu a origem de solos dominantemente arenosos, não propicia o desenvolvimento agrícola sem que haja elevados investimentos. A especificação da utilização do cultivo por culturas cíclicas advém da possibilidade de mecanização favorecida pelo relevo da chapada.

A Zona de Produção com média restrição de produção rural foi recomendada à utilização agropecuária, com o cultivo de pastagens para exploração da pecuária de corte e de leite, além do cultivo de culturas perenes que requeiram um baixo grau de mecanização.

Devido propriamente ao fator topográfico, a ocupação pelas pastagens se fizeram dominantes nos planaltos sedimentares do Taquari e de Maracaju-Campo Grande. Este último compartimento, como já apontado anteriormente, encontra-se utilizado de modo desordenado, pois não se pode atribuir a destinação de uma área agrícola somente pelo fator relevo. Nesse caso, os aspectos litológicos e pedológicos devem ser considerados. Os arenitos do grupo Bauru, que sustentam esse relevo tabular, são constituídos, segundo Brasil (1997), por grânulos e seixos esparsos, matriz argilosa, vermelha, geralmente silicificados, com seixos arredondados. Os solos que ocorrem sobre este compartimento são pobres quimicamente em bases trocáveis e com significativos teores de alumínio, destacando-se o Latossolo Vermelho Álico, textura média com associação de Neossolo Quartzarênico Álico, ambos com horizonte A moderados e com ocorrência em relevo plano e suave ondulado. Logo, a plantação de forrageira do tipo brachiaria renderia provavelmente mais aos produtores e melhoraria as condições ambientais, aumentando naturalmente a quantidade de matéria orgânica nos solos.

Scopel et al. (2009), ao analisar a expansão das fronteiras agrícolas sobre áreas de cerrado em solos arenosos, destacam que as terras ocupadas por primeiro foram aquelas dos chapadões, que possibilitavam a mecanização, exigida pelo novo processo. As pesquisas possibilitaram o melhoramento do solo e as políticas de crédito permitiram a disponibilidade de capital 
para investir na produção. Com isso, a possibilidade de auferir lucros nas áreas mais propícias à agricultura, a dos chapadões, não envolvia riscos, deixando as demais áreas, aquelas de solos arenosos, na marginalidade, ou melhor, na "reserva". Consequentemente, a pecuária avançou sobre estas áreas mais inférteis.

Em contrapartida, a possibilidade de renda, gerada pelas terras dos chapadões, fez aumentar substancialmente o seu preço e quando essas terras mais propícias estavam se esgotando ou com preço de arrendamento e compra muito alto, as terras de "reserva" passaram a ser incorporadas à produção agrícola. Por isso, nos últimos anos, a incorporação de terras mistas (arenosas) na exploração agrícola aumentou, e até mesmo a soja passou a ser cultivada em Neossolos Quartzarênicos.

Em relação às pastagens, a inovação tecnológica, com o uso de uma gramínea resistente e adaptável como a brachiaria, possibilitou a sua implantação em condições adversas. Todavia, o manejo inadequado da terra e a alta pressão de pastejo determinam o seu esgotamento, em poucos anos de uso, sendo muitas áreas posteriormente abandonadas.

Nesse sentido, as áreas recomendadas à utilização pecuária, devem respeitar além dos limites adequados de suporte de cabeças por hectare os cuidados com as matas ciliares e os remanescentes florestais, caso contrário ocorrerá uma forte degradação marcada pela presença de incisões erosivas lineares, voçorocas, assoreamento e secas de cursos d'água e grandes áreas de solo exposto denominados "areais", a exemplo do sudoeste de Goiás que se encontra em alto estágio de degradação atingindo milhares de hectares. A degradação destas áreas evidencia-se pela presença de muitas incisões erosivas lineares, com voçorocas de grande porte, baixa capacidade de suporte da pastagem, assoreamento e seca de cursos d’água e grandes áreas com solo exposto.

As áreas mapeadas com alto grau de restrição foram destinadas à exploração agroflorestal pela silvicultura, com a introdução de eucalipto nas áreas com inclinações superiores a 20\% e situadas em áreas de elevada fragilidade ambiental. Recomenda-se ainda, como fonte de renda alternativa, o plantio de seringueira.

Na exploração da seringueira, o longo período entre a fase de plantio e o início de exploração é um fato que desestimula a atração de investidores, sendo também a razão do manejo ineficiente em alguns plantios. Uma alternativa à solução deste problema é o emprego de sistemas agroflorestais que envolvam o plantio de culturas intercalares de ciclo curto e semiperene. Na fase adulta do seringal é oportuna à consorciação com culturas perenes, a fim de adicionar receitas ao sistema explorado. Tais estratégias são eficazes por antecipar a fase produtiva, adicionar valor, permitir um melhor desenvolvimento dos cultivos e assegurar o incremento da renda na fase adulta (Virgens Filho; Alvim, Araújo, 1987).

Os sistemas agroflorestais (SAF) com a seringueira, quando devidamente planejados, permitem a exploração dos recursos naturais com menores impactos ao meio ambiente. Esse fato se reveste de importância, uma vez que a agricultura comercial, quase sempre focada na produção e na renda, relega a um plano secundário a sustentabilidade dos recursos naturais.

As recomendações para a área urbana referem-se aos cuidados com relação a sua expansão, de modo a evitar a ocupação às margens do rio Coxim, a fim de se reduzir os impactos sobre o mesmo e concomitantemente evitar problemas relacionados a enchentes e inundações. Desta forma sugere-se a expansão nos sentidos norte e oeste. 


\section{Considerações finais}

Pautada na combinação de elementos do meio físico - como solo, relevo, potencial natural à erosão, uso da terra/cobertura vegetal -, legislação ambiental e técnicas de geoprocessamento, a metodologia proposta para o zoneamento ambiental da BAC resultou num importante modelo de subsídio para o ordenamento territorial rural.

As diretrizes elaboradas a partir desse zoneamento ambiental chegaram às seguintes recomendações:

- nas áreas de preservação permanente, incluir os remanescentes florestais, o que, devido à intensa pressão antrópica e ao elevado potencial natural de erosão, é extremamente necessário, visto que o Código Florestal Brasileiro prevê a possibilidade dessa inclusão, fundamental para a redução do potencial erosivo;

- recuperar as Zonas de Incongruências pelo apoio governamental, com o fornecimento de mudas nativas aos proprietários rurais para reflorestamento das áreas ocupadas ilegalmente;

- incentivar a exploração agroflorestal nas Zonas Produtivas de Alta Restrição como alternativa de uso sustentável; por exemplo, o cultivo da seringueira consorciada com palmitos; e

- nas Zonas de Média Restrição que se encontram ocupadas por agricultura, incentivar a alternância de pastagem e agricultura, e, nas demais áreas, o uso pela pecuária leiteira e de corte.

\section{Referências}

ABDON, M. M. Os impactos ambientais no meio físico: erosão e assoreamento na bacia hidrográfica do rio Taquari, MS, em decorrência da pecuária. Tese (Doutorado em Ciências da Engenharia Ambiental) - Escola de Engenharia de São Carlos, Universidade de São Paulo, São Carlos, 2004.

BECKER, B. K.; EGLER, C. A. G. Detalhamento da metodologia para execução do zoneamento ecológico-econômico pelos estados da Amazônia Legal. Brasília: SAE-Secretaria de Assuntos Estratégicos/MMA-Ministério do Meio Ambiente, 1996.

BRASIL. Resolução CONAMA n. 302, de 20 de março de 2002. Dispõe sobre os parâmetros, definições e limites de Áreas de Preservação Permanente de reservatórios artificiais e o regime de uso do entorno, $2002 \mathrm{a}$.

BRASIL. Resolução CONAMA n. 303, de 20 de março de 2002. Dispõe sobre parâmetros, definições e limites de Áreas de Preservação Permanente, 2002b.

BRASIL. Plano de conservação da bacia do alto Paraguai: análise integrada e prognóstico da Bacia do Alto Paraguai. Brasília: PNMA, 1997.

BRASIL. Embrapa. Zoneamento Agroecológico do Nordeste: diagnóstico do quadro natural e agrosocioeconômico. Petrolina: Embrapa/CPATSA, 1991.

BRASIL. Ministério das Minas e Energia. Secretaria Geral. Projeto RADAMBRASIL: geologia, geomorfologia, pedologia, vegetação e uso potencial da terra. Rio de Janeiro, 1982. Folha SE. 21 Corumbá e parte da Folha SE 20. 
BRASIL. Lei n. 4.771, de 15 de setembro de 1965. Dispõe sobre o Código Florestal Brasileiro. Diário Oficial da União, Brasilia, DF, 15 set. 1965.

CREPANI, E.; MEDEIROS, J. S.; FILHO, P. H.; FLORENZANO, T. G.; DUARTE, V.; BARBOSA, C. C. F. Sensoriamento remoto e geoprocessamento aplicados ao zoneamento ecológico-econômico e ao ordenamento territorial. São José dos Campos: SAE/Inpe, 2001 .

MATO GROSSO DO SUL. Atlas Multirreferencial. Campo Grande: Secretaria de Planejamento e Coordenação Geral - Seplan, 1990. Escala 1:1.500.000.

MATO GROSSO DO SUL. IBGE: macrozoneamento geoambiental do estado de Mato Grosso do Sul. Campo Grande: Fiplan, 1987. Escala 1:1.000.000.

PALMEIRA, A. F; CREPANI, E.; MEDEIROS, J. S. Uso de técnicas de sensoriamento remoto e geoprocessamento na proposta de um mapa de ordenamento territorial do município de Paragominas (PA), In: SIMPÓSIO BRASILEIRO DE SENSORIAMENTO REMOTO, XII., 2005, Goiânia. Anais... São José dos Campos: Inpe, 2005. p. 32073214 .

ROSS, J. L. S. Análise empírica da fragilidade dos ambientes naturais e antropizados. Revista do Departamento de Geografia, São Paulo, n. 8, p. 63-74, 1994.

ROSS, J. L. S. Ecogeografia do Brasil. São Paulo: Oficina de Textos, 2006.

ROSS, J. L. S. O registro cartográfico dos fatos geomórficos e a questão da taxonomia do relevo. Revista do Departamento de Geografia, São Paulo, n. 6, p. 17-30, 1992.

SCOPEL, I.; SOUSA, M. S.; PEIXINHO, D. M.; MARIANO, Z. F; MENEZES, B. Novas fronteiras agrícolas: solos arenosos e tecnologias atuais. In: ENCONTRO DE GEÓGRAFOS DA AMÉRICA LATINA, 12., 2009, Montevidéu. Anais... Montevidéu, 2009.

SILVA, J. S. V. Análise multivariada em zoneamento para planejamento ambiental, estudo de caso: bacia hidrográfica do alto rio Taquari MS/MT. Tese (Doutorado em Engenharia Agrícola) - Faculdade de Engenharia Agrícola, Universidade Estadual de Campinas, Campinas, 2003.

TRICART, J. Ecodinâmica. Rio de Janeiro: IBGE/Supren (Recursos Naturais e Meio Ambiente), 1977.

; KIEWIETDEJONGE, C. Ecogeography and Rural Management: A Contribuition to the International Geosphere-Biosphere Programme. New York : Longman Scientific \& Technical, 1992.

VALERIANO, M. M. Topodata: guia de utilização de dados geomorfométricos locais. São José dos Campos: Inpe, 2008.

VIRGENS FILHO, A. C.; ALVIN, R.; ARAÚJO, A. C. Plantio de cacaueiros sob seringais adultos na região sul da Bahia. In: INTERNATIONAL COCOA RESEARCH CONFERENCE. CONFERÊNCIA INTERNACIONAL DE PESQUISAS EM CACAU, 10., 1987, Santo Domingo. Anais... Santo Domingo, 1987. p. 33-41. 